\title{
Spijbelen onder scholieren: de rol van een zorgsituatie thuis
}

\author{
Ingrid van Tienen · Simone de Roos · Alice de Boer
}

Published online: 13 February 2020

(C) The Author(s) 2020

Samenvatting In dit artikel gaan we na of het hebben van een langdurig ziek gezinslid bij scholieren samenhangt met spijbelgedrag. De gegevens zijn afkomstig van het Health Behaviour in School-aged Childrenonderzoek uit 2013, een representatief onderzoek onder Nederlandse middelbare scholieren die het regulier onderwijs bezoeken in de leeftijd van twaalf tot en met zestien jaar ( $n=5.168)$. Behalve naar spijbelen en het hebben van een ziek gezinslid is gekeken naar sociaal-demografische kenmerken en ervaren sociale steun. Een op de tien scholieren rapporteert minstens één lesuur te hebben gespijbeld in de maand voorafgaand aan het onderzoek. Scholieren met een langdurig ziek gezinslid zijn vergeleken met scholieren zonder ziek gezinslid vaker meisjes, maken vaker deel uit van gezinnen met een lagere gezinswelvaart, komen vaker uit onvolledige gezinnen en ervaren minder steun thuis. Vergeleken met andere scholieren spijbelen scholieren met een langdurig ziek gezinslid niet vaker, maar wel meer lesuren, ook na correctie voor sociaal-demografische kenmerken en sociale steun. Steun van leraren en vrienden hangt samen met het al dan niet spijbelen en steun thuis is gerelateerd aan het aantal spijbeluren. Het versterken van steun in zowel de thuissituatie als de schoolsetting is van belang voor het reduceren van spijbelgedrag van scholieren, in het bijzonder voor scholieren met een langdurig zieke thuis.

\author{
I. van Tienen $(\varangle) \cdot$ A. de Boer \\ Vrije Universiteit Amsterdam, Amsterdam, Nederland \\ I.van.tienen@vu.nl \\ S. de Roos · A. de Boer \\ Sociaal en Cultureel Planbureau, Den Haag, Nederland
}

Trefwoorden spijbelen · verzuim • jonge mantelzorgers · langdurig zieke gezinsleden · scholieren

\section{Truancy among students: the role of having a chronically ill family member}

Abstract This paper investigates if having a chronically ill family member (being a young carer) has a unique effect on truancy in students. The data used come from the Health Behaviour in School-aged Children study gathered in 2013. The sample consists of students aged 12 to 16 years $(n=5,168)$. One in ten students reports being truant for at least one period during the last month. Besides truancy, we also

\section{Kernpunten}

- In 2013 gaf een op de tien scholieren op het regulier onderwijs aan minstens één lesuur te hebben gespijbeld in de maand voorafgaand aan het onderzoek.

- Scholieren met een langdurig ziek gezinslid spijbelen niet vaker, maar wel meer lesuren dan leeftijdgenoten zonder een langdurig ziek gezinslid.

- Vergeleken met scholieren zonder langdurig ziek gezinslid komen meisjes, gezinnen met een lage welvaart en gezinnen waarin niet beide ouders aanwezig zijn (onvolledige gezinnen) vaker voor in de groep met een langdurig ziek gezinslid. Ook ontvangen scholieren met een langdurig ziek gezinslid thuis minder steun.

- Los van demografische kenmerken en sociale steun vormt de zorgsituatie thuis een unieke risicofactor voor het aantal spijbeluren bij scholieren. 
studied the role of sociodemographic characteristics and perceived support. Students with and without a chronically ill family member differ in sex (more often female), family affluence (less affluent), family composition (more often incomplete families) and perceived support from their family (less support). After controlling for sociodemographic characteristics and perceived support from family, friends and teachers, young carers do not play truant more often than non-carers, but are truant at a more intense level (more periods). Support from teachers and friends is related to playing truant, support at home is related to the intensity of truancy. Reinforcing support at school and at home seems to be of importance in reducing truancy in students, in particular for young carers.

Keywords Truancy · School absenteeism · Young carers · Chronically ill family members · Students

\section{Inleiding}

Op middelbare scholen komt spijbelen, oftewel afwezigheid zonder geldige reden, geregeld voor [1, 2]. Spijbelen gaat vaak gepaard met slechtere schoolprestaties, schoolvertraging en een grote kans op vroegtijdig schoolverlaten. Het gebrek aan een startkwalificatie kan vervolgens zorgen voor slechtere kansen op de arbeidsmarkt en een grotere kans om werkloos te worden en afhankelijk te zijn van sociale zekerheidsvoorzieningen [3-5]. De aanpak van spijbelen staat al lange tijd op de agenda van beleidsmakers. Het huidige kabinet heeft de ambitie uitgesproken om spijbelen vroegtijdig te signaleren en aan te pakken. Om spijbelen te kunnen voorkomen of inperken is het van belang te weten welke factoren er een rol bij kunnen spelen.

Uit de literatuur blijkt dat naast factoren op het niveau van het kind (bijvoorbeeld faalangst), de school (bijvoorbeeld een onveilig schoolklimaat, beperkte steun van leraren) en leeftijdgenoten (bijvoorbeeld druk van vrienden), ook verschillende gezinsfactoren van belang kunnen zijn [6-8]. Te denken valt aan demografische aspecten, zoals de gezinsstructuur en gezinswelvaart, en aan psychosociale aspecten binnen het gezin, zoals de onderlinge relaties, ervaren steun en ouderlijke supervisie [9-13].

Een gezinsfactor die mogelijk ook bijdraagt aan spijbelgedrag, maar nog weinig is onderzocht, is het opgroeien met een langdurig ziek gezinslid. In Nederland heeft een substantieel deel van de jongeren hiermee te maken, ongeveer een op de tien scholieren in de leeftijd van dertien tot zeventien jaar [14]. Zij groeien op met een naaste - zoals een ouder, broer of zus - die in bepaalde mate afhankelijk is van zorg en ondersteuning van anderen, bijvoorbeeld vanwege een ernstige ziekte of handicap, een psychiatrische aandoening, verslavingsproblematiek of een verstandelijke beperking [14-16]. Deze jongeren worden ook wel jonge mantelzorgers genoemd en staan volop in de maatschappelijke en politieke belangstelling [17, 18]. Zo stelt minister Hugo de Jonge dat de eigen kracht van deze jongeren moet worden versterkt en mogelijke psychische en schoolproblemen (waaronder spijbelen) moeten worden voorkomen [17].

Er zijn aanwijzingen uit eerder lokaal en internationaal onderzoek dat jongeren met een ziek gezinslid vaker hun huiswerk niet afkrijgen en ook vaker spijbelen dan jongeren zonder een ziek gezinslid [19-21]. Landelijk representatief onderzoek naar het verband tussen het opgroeien met een langdurig ziek gezinslid en spijbelen ontbreekt echter, en er is weinig bekend over het relatieve belang van een zorgsituatie thuis en de rol van andere factoren die mogelijk ook samenhangen met de zorgsituatie, zoals het opgroeien in een eenoudergezin of het ervaren van weinig steun thuis.

In dit artikel geven we inzicht in het spijbelgedrag van scholieren met een langdurig ziek gezinslid. Hiervoor onderzoeken we in hoeverre scholieren met en zonder langdurig ziek gezinslid zich onderscheiden wat betreft hun sociaal-demografische kenmerken en ervaren steun van hun gezin, vrienden en leraren (eerste onderzoeksvraag). Daarnaast kijken we naar de relatie tussen spijbelen en het hebben van een ziek gezinslid, waarbij we controleren voor verschillende achtergrondkenmerken (tweede onderzoeksvraag).

$\mathrm{Er}$ is sprake van een langdurige zorgsituatie thuis als een huisgenoot langer dan drie maanden lichamelijk of psychisch ziek is. Omwille van de leesbaarheid wisselen we in de tekst 'een langdurig ziek gezinslid' af met een 'zorgsituatie thuis', waarmee we hetzelfde bedoelen.

\section{Balansmodel}

Om spijbelgedrag van scholieren te relateren aan een zorgsituatie thuis maken we gebruik van het Balansmodel van Bakker en collega's [22]. Volgens dit model hangt de ontwikkeling van (probleem)gedrag zoals spijbelen samen met de balans tussen de ervaren draaglast en draagkracht. De ontwikkelingstaken die een jongere heeft, zoals het naar school gaan, aanleren van vaardigheden en het opdoen van kennis, bepalen de mate van ervaren draaglast. Hiertegenover staat de draagkracht: vaardigheden en hulpbronnen die een jongere heeft om de taken en verplichtingen te volbrengen en moeilijkheden die daarbij ontstaan te incasseren en verwerken. Draaglast en draagkracht worden beïnvloed door het geheel van aanwezige risicoen beschermende factoren die de draaglast verzwaren of de draagkracht vergroten. Risicofactoren voor spijbelen zijn bijvoorbeeld ongunstige sociaal-demografische factoren als het opgroeien in een gezin met een lage gezinswelvaart, een laag opleidingsniveau of een onvolledig gezin (waarin niet beide ouders aanwezig zijn, zoals een eenouder- of stiefgezin) [2, 8-11, 23]. Beschermende factoren zijn bijvoorbeeld steun 
vanuit de sociale omgeving - van ouders en leraren $[12,13]$. Verschillende onderzoeken hebben laten zien dat spijbelgedrag minder vaak voorkomt in gezinnen waar de onderlinge relaties hecht zijn en ouders betrokken zijn bij hun kind [10-12]. Scholieren die een hechtere band met en meer steun van hun leraren ervaren laten op school vaak betere schoolprestaties en een hoger welbevinden zien, wat weer een verlaagde kans op spijbelen geeft [24, 25]. Onduidelijk is in hoeverre steun van vrienden een buffer tegen spijbelen vormt. Zo blijkt uit eerder onderzoek dat het hebben van veel vrienden samengaat met een lagere kans op spijbelen, maar dat het ontmoeten van vrienden ook een reden kan zijn om te gaan spijbelen [10, 26, 27]. Op basis van het balansmodel gaan we er in dit artikel vanuit dat spijbelgedrag ontstaat vanuit een disbalans tussen draaglast en draagkracht, die veroorzaakt wordt door verschillende risicofactoren en een tekort aan beschermende factoren.

Het hebben van een ziek gezinslid vormt naar verwachting een risicofactor voor het ontstaan of verergeren van problemen van jongeren (waaronder spijbelen) doordat het de draaglast op verschillende manieren kan vergroten. Ten eerste kan de zorgsituatie voor jongeren stress, zorgen en angsten met zich meebrengen, waardoor zij zich minder goed kunnen concentreren op school(taken), wat slechte schoolprestaties en daarmee ook spijbelgedrag tot gevolg kan hebben, bijvoorbeeld doordat jongeren gedemotiveerd raken en/of zich schamen [3-5, 14, 20, 21]. Ook kan het verrichten van (veel) mantelzorgtaken ervoor zorgen dat jongeren minder tijd hebben voor school en gaan spijbelen $[20,21]$. Ten tweede hebben jongeren met een zorgsituatie thuis vergeleken met 'doorsnee' jongeren vaker te maken met ongunstige sociaal-demografische factoren, zoals opgroeien in onvolledige gezinnen en gezinnen met een lagere gezinswelvaart [14, 16].

Ten slotte kan de zorgsituatie gevolgen hebben voor de (beschermende) factor steun binnen en buiten het gezin, wat indirect een effect kan hebben op spijbelgedrag. Binnen het gezin kan de zorgsituatie namelijk leiden tot verminderde betrokkenheid en steun van de ouders, vanwege stress en gebrek aan tijd en ruimte voor de jongeren $[7,8,28,29]$. Ook kan het opgroeien met een ziek gezinslid gevolgen hebben voor sociale contacten buiten het gezin. Zo blijken jongeren in een zorgsituatie moeilijker aansluiting te vinden bij leeftijdgenoten, mogelijk omdat zij vanwege schaamte en taboes niet altijd gemakkelijk over hun situatie kunnen praten en soms ook geen tijd voor vriendschappen hebben [30]. Onbekend is in hoeverre het hebben van een ziek gezinslid invloed kan hebben op de steun die jongeren van hun leraren ervaren. Buitenlands onderzoek doet vermoeden dat de relaties tussen ouders, leerlingen en leraren minder optimaal zijn als er sprake is van een zorgsituatie thuis [31].

\section{Methode}

\section{Dataverzameling en respons}

De gegevens voor dit onderzoek zijn afkomstig van de enquête van het Health Behaviour in School-aged Children (HBSC 2013)-onderzoek [32]. Deze bevat vragen over de gezondheid en het welbevinden, zoals (on)gezonde eetgewoonten, bewegen, schoolbeleving, risicogedrag, psychische problemen, de thuissituatie en de relatie met ouders en vrienden.

De dataverzameling heeft plaatsgevonden in het najaar van 2013 en maakt gebruik van een aselecte steekproef van Nederlandse basisscholen (groep 8) en (de eerste vier klassen van) scholen voor voortgezet onderwijs (regulier onderwijs) (gestratificeerd op stedelijkheidsniveau), geselecteerd op basis van het bestand van de Dienst Uitvoering Onderwijs (DUO). Van de geselecteerde scholen is uit de deelnemende leerjaren willekeurig een klas getrokken. Voor dit artikel is gebruikgemaakt van gegevens van scholieren van het voortgezet (regulier) onderwijs, omdat de basisschoolenquête geen vragen over spijbelgedrag bevat. De respons van scholen in het voortgezet onderwijs was $40 \%$. De voornaamste reden voor scholen om niet aan het onderzoek deel te nemen was omdat zij al betrokken waren bij ander onderzoek of omdat zij aangaven te vaak voor onderzoek benaderd te worden. Er werd gebruikgemaakt van een klassikale afname van de enquête, waarbij in totaal 387 leerlingen (6\%) afwezig waren. Op de absentielijsten werd ziekte genoemd als de voornaamste reden voor afwezigheid en elf leerlingen spijbelden ( $3 \%$ van de afwezigen). Van de 5.718 leerlingen die de vragenlijst invulden zijn er na selectie op de belangrijkste variabelen spijbelen, leeftijd en steun 5.168 leerlingen meegenomen in de analyses.

\section{Meetinstrumenten}

\section{Spijbelen}

Spijbelgedrag is gemeten met de vraag hoeveel lesuren de scholieren in de vier weken voorafgaand aan het onderzoek hebben gespijbeld. Antwoordmogelijkheden waren: 0 lesuren (niet spijbelen), 1 lesuur, 2 lesuren, 3 of 4 lesuren, 5 of 6 lesuren of 7 lesuren of meer. Hiervan is een variabele 'al dan niet spijbelen' en een variabele 'aantal lesuren spijbelen onder de spijbelaars' gemaakt. De antwoordcategorieën ' 3 of 4 lesuren', ' 5 of 6 lesuren' en ' 7 lesuren of meer' zijn respectievelijk gecodeerd als 3,5, 5,5 en 7 uur.

\section{Langdurig ziek gezinslid}

Om te bepalen of er bij scholieren sprake is van een zorgsituatie is gevraagd of er thuis (het huis of gezin waar ze het meest zijn) iemand is die langer dan drie maanden (lichamelijk of psychisch) ziek of gehandicapt is. Er waren meerdere antwoordmogelijkheden: 'ikzelf', 'mijn vader/moeder', 'mijn broer/zus', 'iemand 
anders' en 'niemand'. Scholieren die zelf ziek zijn en geen zieke gezinsleden hebben zijn ingedeeld in de groep zonder ziek gezinslid.

\section{Sociaal-demografische kenmerken}

De leeftijd van respondenten is bepaald door het geboortejaar af te trekken van het afnamejaar. Ook is gevraagd naar de sekse van de jongeren. Op basis van het geboorteland van zowel de scholier als de ouders zijn jongeren in navolging van de CBS-definitie ingedeeld op migratieachtergrond: leerlingen zonder migratieachtergrond, met een westerse migratieachtergrond en met een niet-westerse migratieachtergrond. Schoolniveau is gemeten door te vragen welk van de volgende vier schoolniveaus de scholier volgt: vmbobasis- en kaderberoepsgerichte leerweg (vmbo-b/k), vmbo-theoretisch en gemengde leerweg (vmbo-t/g), havo, vwo.

Of scholieren opgroeien in een volledig (met beide biologische of adoptieouders in één huis) of een onvolledig gezin (bijvoorbeeld een eenoudergezin of stiefgezin) is nagegaan met de vragen of jongeren met beide ouders in hetzelfde huis wonen en welke mensen er woonachtig zijn in het huis waar zij het vaakst verblijven. Er waren meerdere antwoordmogelijkheden (bijvoorbeeld moeder, vader, (half)broers(s), (half)zus(sen)), en scholieren konden zelf personen toevoegen. Ook is gevraagd of ze nog een ander huis of gezin hebben, en zo ja, wie daar wonen. De mate van gezinswelvaart is gemeten door te vragen naar concrete bezittingen (zoals aantal auto's of computers), kenmerken van het huis (aantal badkamers en eigen slaapkamer) en het aantal vakanties naar het buitenland in het afgelopen jaar, ontleend aan de Family Affluence Scale (FAS) [33]. Aan de hand van de somscore (0-13) zijn de jongeren in drie groepen verdeeld: gezinnen met een laag (0-6), gemiddeld (7-9) of hoog welvaartsniveau (10-13) [32].

\section{Ervaren steun}

De ervaren steun van het gezin is in kaart gebracht via een viertal stellingen, ontleend aan de Multidimensional Scale of Perceived Social Support (MSPSS) [34]. Een voorbeeldstelling is: 'Ik krijg thuis de emotionele steun en hulp die ik nodig heb.' Er zijn zeven antwoordcategorieën die lopen van 'helemaal niet mee eens (1)' tot 'heel erg mee eens (7)'. Op basis van de gemiddelde score op de stellingen is een schaal gemaakt (van $1=$ geen steun tot $7=$ heel veel steun, $\alpha=0,91)$.

Steun van vrienden is ook met vier stellingen van de MSPSS gemeten (bijvoorbeeld 'mijn vrienden proberen mij echt te helpen'), met zeven antwoordcategorieën van 'helemaal niet mee eens (1)' tot 'heel erg mee eens (7)'. Op basis van de gemiddelde score op de stellingen is een schaal gemaakt (van $1=$ geen steun tot $7=$ heel veel steun, $\alpha=0,93$ ).

Daarnaast is met een drietal stellingen gekeken in hoeverre scholieren steun ervaren van leraren. Hen is gevraagd of ze het gevoel hebben dat leraren hen accepteren en om hen geven, en of zij vertrouwen hebben in hun leraren. Ze antwoordden op een vijfpuntsschaal (van $1=$ 'heel erg mee eens' tot $5=$ 'heel erg niet mee eens'). De antwoordmogelijkheden zijn omgepoold, zodat een hogere score meer ontvangen steun betekent. Er is een schaal gemaakt op basis van de gemiddelde score $(\alpha=0,83)$ (van $1=$ geen steun tot en met $5=$ heel veel steun).

\section{Data-analyse}

De analyses zijn uitgevoerd in Stata 14. Er is een weegfactor toegepast voor stedelijkheidsniveau, sekse, leerjaar en schoolniveau, en gecontroleerd voor het feit dat scholieren genest zijn binnen scholen. Voor het beantwoorden van de onderzoeksvraag naar verschillen in achtergrondkenmerken en steun tussen scholieren met en zonder ziek gezinslid zijn beschrijvende analyses uitgevoerd. Vanwege de scheve verdeling van de afhankelijke (tel)variabele spijbelen en het overschot op de nul (omdat er meer scholieren zijn die niet spijbelen dan scholieren die wel spijbelen) is er voor de hoofdvraag gebruikgemaakt van een zero-inflated negatief binomiale regressie (zinb-regressie) [35]. In de zinb-regressie worden twee processen tegelijkertijd gemodelleerd, namelijk of respondenten al dan niet spijbelen (effect op de nullen) en hoeveel uren spijbelaars spijbelen (effect op waarden boven de nul).

\section{Resultaten}

De steekproef bestaat uit 5.168 scholieren, van wie 4.582 geen ziek gezinslid hebben en 586 scholieren wel een ziek gezinslid hebben (tab. 1). Op basis van de gegevens van tab. 1 geven we een antwoord op de eerste onderzoeksvraag: op welke kenmerken onderscheiden scholieren met en zonder zorgsituatie zich van elkaar? Scholieren met en zonder ziek gezinslid zijn vergelijkbaar wat betreft leeftijd, schoolniveau en steun van vrienden en leraren. Meisjes geven wel vaker dan jongens aan op te groeien met een ziek gezinslid ( $54 \%$ versus $46 \%$ ). Daarnaast rapporteren scholieren uit onvolledige gezinnen vaker zieke gezinsleden, waar scholieren uit gezinnen met een hogere gezinswelvaart minder vaak zieke gezinsleden rapporteren. De resultaten laten ook zien dat scholieren met een ziek gezinslid minder steun van hun gezin ontvangen dan scholieren zonder ziek gezinslid.

Van de scholieren zonder langdurig ziek gezinslid spijbelt bijna $10 \%$, tegenover ruim $9 \%$ van de scholieren met een langdurig ziek gezinslid. Dit verschil is niet significant (tab. 1). Scholieren met een langdurig ziek gezinslid spijbelen wel significant meer lesuren dan scholieren zonder langdurig ziek gezinslid: gemiddeld 3,3 lesuren, tegenover 2,4 lesuren. Scholieren met een langdurig ziek gezinslid spijbelen ook vaker 2 lesuren en nog vaker 5,5 en 7 of meer lesuren, 
Tabel 1 Beschrijvende statistiek van de totale populatie scholieren en degenen zonder/met een langdurig ziek gezinslid (gewogen percentages/gemiddelden (standaardfout (se))) $^{\text {a }}$

\begin{tabular}{|c|c|c|c|c|c|c|c|}
\hline & \multicolumn{2}{|c|}{ Totale groep $(n=5.168)$} & \multicolumn{2}{|c|}{$\begin{array}{l}\text { Scholieren } \\
\text { zonder langdurig ziek gezinslid } \\
(n=4.582)\end{array}$} & \multicolumn{3}{|c|}{$\begin{array}{l}\text { Scholieren met een langdurig ziek gezinslid } \\
(n=586)\end{array}$} \\
\hline & m (se) & $\%$ & m (se) & $\%$ & $\mathrm{~m}(\mathrm{se})$ & $\%$ & $p$ \\
\hline Spijbelen $^{b}$ & & 9,8 & & 9,9 & & 9,4 & \\
\hline $\begin{array}{l}\text { Aantal lesuren } \\
\text { gespijbeld }\end{array}$ & $2,5(0,1)$ & & $2,4(0,1)$ & & $3,3(0,3)$ & & * \\
\hline Leeftijd & $13,9(0,0)$ & & $13,9(0,0)$ & & $13,9(0,1)$ & & \\
\hline-12 jaar & & 16,8 & & 16,9 & & 16,0 & \\
\hline-13 jaar & & 22,2 & & 22,1 & & 23,6 & \\
\hline-14 jaar & & 24,9 & & 25,2 & & 21,8 & \\
\hline-15 jaar & & 23,3 & & 22,8 & & 27,3 & \\
\hline-16 jaar & & 12,8 & & 11,3 & & 13,0 & \\
\hline \multicolumn{8}{|l|}{ Geslacht } \\
\hline - Jongen & & 50,3 & & 50,8 & & 46,0 & \\
\hline - Meisje & & 49,7 & & 49,2 & & 54,1 & * \\
\hline \multicolumn{8}{|l|}{ Schoolniveau } \\
\hline - vmbo-b/k & & 23,4 & & 23,1 & & 26,1 & \\
\hline - vmbo-t/g & & 27,1 & & 27,1 & & 27,3 & \\
\hline - havo & & 26,9 & & 27,2 & & 25,3 & \\
\hline- vwo & & 22,5 & & 22,7 & & 21,3 & \\
\hline \multicolumn{8}{|l|}{ Etniciteit } \\
\hline $\begin{array}{l}\text { - Geen migratieach- } \\
\text { tergrond }\end{array}$ & & 79,5 & & 79,5 & & 79,8 & \\
\hline $\begin{array}{l}\text { - Niet-westers mi- } \\
\text { grant }\end{array}$ & & 14,8 & & 14,8 & & 14,9 & \\
\hline - Westers migrant & & 5,7 & & 5,7 & & 5,4 & \\
\hline \multicolumn{8}{|l|}{ Gezinswelvaart } \\
\hline - Laag & & 12,2 & & 11,9 & & 14,9 & \\
\hline - Midden & & 55,8 & & 55 & & 61,8 & \\
\hline - Hoog & & 32 & & 33,1 & & 23,3 & $\ddagger$ \\
\hline \multicolumn{8}{|l|}{ Gezinsvorm } \\
\hline - Onvolledig gezin & & 73,7 & & 25,6 & & 31,5 & $\ddagger$ \\
\hline - Volledig gezin & & 26,3 & & 74,4 & & 68,5 & \\
\hline \multicolumn{8}{|l|}{ Ervaren steun ${ }^{d}$} \\
\hline - Thuis & $5,9(0,0)$ & & $5,9(0,0)$ & & $5,7(0,1)$ & & * \\
\hline - Vrienden & $5,8(0,0)$ & & $5,8(0,0)$ & & $5,8(0,1)$ & & \\
\hline - Leraren & $3,8(0,0)$ & & $3,8(0,0)$ & & $3,7(0,0)$ & & \\
\hline \multicolumn{8}{|c|}{ 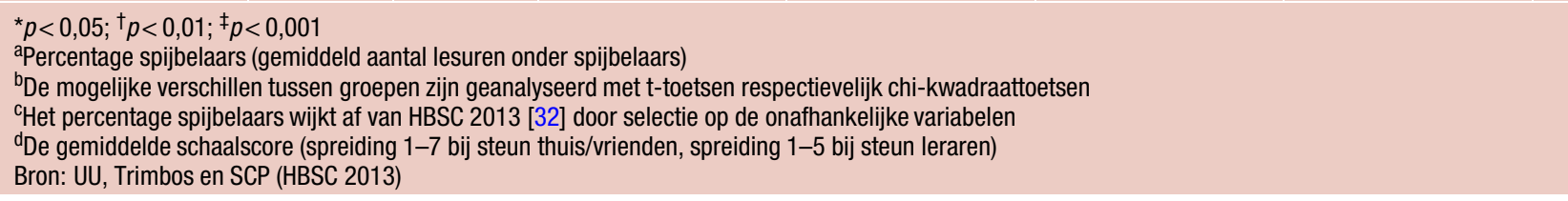 } \\
\hline
\end{tabular}

bij de scholieren zonder een langdurig ziek gezinslid ligt deze spijbelintensiteit lager (fig. 1).

De tweede onderzoeksvraag, over de relatie tussen spijbelgedrag en een zorgsituatie bij scholieren thuis, is te beantwoorden op basis van de gegevens in tab. 2 . Multivariate zinb-regressieanalyses laten zien dat een zorgsituatie thuis niet gerelateerd is aan het al dan niet spijbelen (eerste kolom, $\mathrm{B}=-0,41$, niet significant). De tweede kolom in tab. 2 laat zien dat een zorgsituatie thuis uniek gerelateerd is aan het aantal lesuren spijbelen $(\mathrm{B}=0,58, p<0,01)$.

Meisjes blijken minder vaak te spijbelen dan jongens $(B=-0,50, p<0,01)$ en scholieren spijbelen vaker naarmate ze ouder zijn. Scholieren met een westerse migratieachtergrond $(\mathrm{B}=0,75, p<0,05)$ en scholieren uit een onvolledig gezin $(\mathrm{B}=0,30, p<0,05)$ spijbelen ook vaker dan scholieren die geen migratieachtergrond hebben en bij beide ouders opgroeien. Er is een significante samenhang van steun van vrien- 
Figuur 1 Aantal lesuren spijbelen in de 4 weken voorafgaand aan het onderzoek onder spijbelaars; scholieren zonder/met langdurig ziek gezinslid $(n=481)$. Bron: UU, Trimbos en SCP (HBSC 2013)

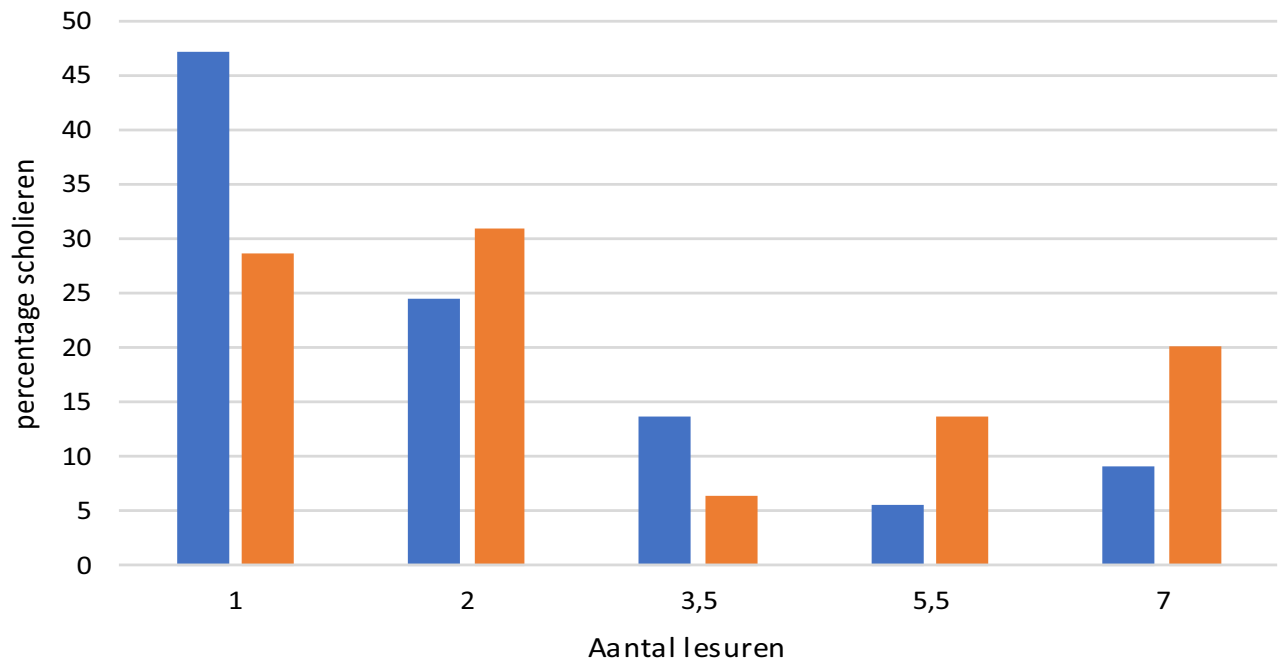

Aantal lesuren

- Scholieren zonder langdurig ziek gezinslid Scholieren met langdurig ziek gezinslid

den met spijbelen: naarmate jongeren meer steun van vrienden ervaren hebben zij vaker gespijbeld $(B=0,12$, $p<0,05)$. Steun van leraren heeft een negatief verband met spijbelen $(B=-0,63, p<0,001)$, wat erop duidt dat scholieren minder vaak spijbelen naarmate zij meer steun van leraren ontvangen. $\mathrm{Er}$ is een negatieve samenhang van ontvangen steun van het gezin op het aantal gespijbelde lesuren $(\mathrm{B}=-0,11, p<0,05)$, wat erop wijst dat scholieren minder lesuren spijbelen wanneer ze thuis meer steun ervaren. Totaal verklaart het model $13 \%$ van de variantie.

\section{Beschouwing}

De eerste onderzoeksvraag betrof het verschil in sociaal-demografische kenmerken en ervaren steun tussen scholieren met en zonder een zorgsituatie thuis. Een zorgsituatie thuis is opgevat als het hebben van een lichamelijk of psychisch ziek of gehandicapt gezinslid dat drie maanden of langer ziek is. De scholieren met een zorgsituatie thuis onderscheiden zich van andere scholieren wat betreft hun geslacht (vaker meisjes), gezinswelvaart (vaker lager), gezinsvorm (vaker onvolledige gezinnen) en ervaren steun (minder steun thuis). Er zijn geen verschillen wat betreft hun leeftijd, etniciteit, schoolniveau en steun van vrienden en leraren. Deze bevindingen komen overeen met die van eerder onderzoek [14, 16, 19].

Het is niet aannemelijk dat meisjes vaker te maken hebben met een zorgsituatie, maar zij rapporteren dit mogelijk wel eerder door een hogere mate van sensitiviteit voor problemen die in het gezin spelen [19]. De verschillen in gezinskenmerken laten zien dat een zorgsituatie thuis vaak samengaat met andere minder gunstige leefomstandigheden, zoals het opgroeien in een eenoudergezin, een lagere welvaart en minder steun vanuit het gezin.

De tweede onderzoeksvraag was in hoeverre een zorgsituatie thuis bij scholieren (uniek) samenhangt met spijbelgedrag wanneer er rekening wordt gehouden met sociaal-demografische kenmerken en steun. Een op de tien van de scholieren spijbelde in 2013, dat wil zeggen minstens één lesuur in vier weken voorafgaand aan het onderzoek. Scholieren met een langdurig ziek gezinslid spijbelen niet vaker, maar wel meer lesuren, vergeleken met andere leeftijdgenoten. De multivariate regressieanalyse laat zien dat de samenhang tussen zorgsituatie en spijbelintensiteit overeind blijft, na correctie voor sociaal-demografische kenmerken en steun. Wel is het verband tussen een zorgsituatie en het aantal lesuren spijbelen mogelijk sterker dan uit dit onderzoek naar voren komt. De resultaten laten zien dat scholieren met een zorgsituatie sterk oververtegenwoordigd zijn bij 5,5 en 7 lesuren of meer. Omdat er een afkappunt is toegepast dat jongeren die 7 of meer lesuren spijbelen 'vastzet' op een maximum van 7 spijbeluren is echter niet zichtbaar om hoeveel lesuren het daadwerkelijk gaat. Een mogelijke verklaring voor de relatie tussen zorgsituatie thuis en spijbelintensiteit is dat een zorgsituatie veel tijd en aandacht vraagt, waardoor scholieren meer uren gaan spijbelen om voor het zieke gezinslid te kunnen zorgen. In eerder (kwalitatief) onderzoek gaven scholieren met een zorgsituatie thuis aan dat zij vaak thuis blijven om hulp te kunnen bieden of voor een broertje of zusje te zorgen [20, 36]. Een andere verklaring is dat scholieren zich door de zorgsituatie emotioneel zwaar belast voelen en proberen de thuissituatie even te vergeten door langer te spijbelen.

Risicofactoren voor spijbelen bleken het zijn van een jongen, een hogere leeftijd hebben, een (westerse) migratieachtergrond hebben en opgroeien in een onvolledig gezin, zoals eerdere onderzoeken ook al uitwezen [8, 9, 23, 27]. De ervaren steun bleek deels een beschermende factor voor zowel het al dan niet spijbelen als de spijbelintensiteit. Scholieren spijbelen namelijk minder vaak naarmate zij meer steun van leraren ervaren en rapporteren minder lesuren te spij- 
Tabel 2 Samenhang tussen het hebben van een langdurig ziek gezinslid, sociaal-demografische kenmerken en ervaren steun enerzijds, en spijbelen en aantal lesuren spijbelen bij scholieren anderzijds $(n=5.168)^{\text {a }}$

\begin{tabular}{|c|c|c|}
\hline & Spijbelen (niet/wel) $(n=4.687)$ & Aantal lesuren spijbelen $>0(n=481)$ \\
\hline & $\mathrm{B}(\mathrm{se})^{b}$ & $\mathrm{~B}(\mathrm{se})^{b}$ \\
\hline \multicolumn{3}{|c|}{ Langdurig ziek gezinslid (geen langdurig ziek gezinslid) } \\
\hline - Wel een langdurig ziek gezinslid & $-0,41(0,21)$ & $0,58(0,17)^{\dagger}$ \\
\hline \multicolumn{3}{|l|}{ Geslacht (jongen) } \\
\hline - Meisje & $-0,50(0,18)^{\dagger}$ & $0,17(0,15)$ \\
\hline \multicolumn{3}{|l|}{ Leeftijd (12 jaar) } \\
\hline - 13 jaar & $0,64(0,39)^{\star}$ & $0,26(0,36)$ \\
\hline-14 jaar & $1,32(0,43)^{\dagger}$ & $0,25(0,47)$ \\
\hline-15 jaar & $1,67(0,43)^{\ddagger}$ & $0,36(0,41)$ \\
\hline-16 jaar & $1,90(0,42)^{\ddagger}$ & $0,49(0,44)$ \\
\hline \multicolumn{3}{|l|}{ Schoolniveau (vmbo-b/k) } \\
\hline - vmbo-t/g & $0,15(0,29)$ & $-0,18(0,17)$ \\
\hline - havo & $0,24(0,28)$ & $-0,15(0,19)$ \\
\hline- vwo & $-0,42(0,34)$ & $-0,26(0,18)$ \\
\hline \multicolumn{3}{|l|}{ Migratieachtergrond (geen) } \\
\hline - Niet-westers migrant & $0,36(0,27)$ & $0,02(0,19)$ \\
\hline - Westers migrant & $0,75(0,37)^{\star}$ & $0,03(0,24)$ \\
\hline \multicolumn{3}{|l|}{ Gezinswelvaart (laag) } \\
\hline - Midden & $0,06(0,23)$ & $0,09(0,19)$ \\
\hline - Hoog & $0,41(0,28)$ & $0,16(0,22)$ \\
\hline \multicolumn{3}{|l|}{ Gezinsvorm (volledig gezin) } \\
\hline - Onvolledig gezin & $0,30(0,14)^{*}$ & $0,17(0,12)$ \\
\hline \multicolumn{3}{|l|}{ Ervaren steun } \\
\hline - Thuis & $-0,10(0,06)$ & $-0,11(0,04)^{\star}$ \\
\hline - Vrienden & $0,12(0,05)^{\star}$ & $-0,08(0,05)$ \\
\hline - Leraren & $-0,63(0,09)^{\ddagger}$ & $-0,09(0,08)$ \\
\hline Constante & 0,56 & 1,01 \\
\hline $\mathrm{R}^{2}$ (ongewogen) & & 0,13 \\
\hline $\begin{array}{l}{ }^{*} p<0,05 ;{ }^{\dagger} p<0,01 ;{ }^{\ddagger} p<0,001 \\
\text { aZero-inflated negatief binomiale regressie } \\
\text { bOngestandaardiseerde coêfficiënten } \\
\text { Bron: UU, Trimbos en SCP (HBSC 2013) }\end{array}$ & & \\
\hline
\end{tabular}

belen wanneer zij thuis meer steun ervaren. Jongeren spijbelen echter vaker naarmate zij meer steun van vrienden ontvangen. Dit zou verklaard kunnen worden vanuit het sociale aspect van spijbelen, omdat spijbelen een manier kan zijn om contact met (bepaalde) vrienden te versterken [10, 37]. Vervolgonderzoek naar de rol die vrienden bij spijbelen spelen zou zich kunnen richten op kenmerken van vrienden. Mogelijk zijn dit vooral vrienden die veel risicogedrag vertonen, zoals drugsgebruik [38]. Onze resultaten suggereren dat de inzet van steun mogelijk een goede interventie is om spijbelgedrag te verminderen, al is ook van belang wie de steun biedt. Steun van school of het gezin is daarbij een beschermende factor; steun van (bepaalde) vrienden is mogelijk een risicofactor.

Het balansmodel met draaglast- en draagkrachtfactoren geeft een beter begrip van spijbelgedrag bij scholieren [22]. Het hebben van een langdurig ziek gezinslid blijkt draaglast verhogend te werken (omdat het de kans op meer lesuren spijbelen doet toene- men), terwijl steun van het gezin en leraren de draagkracht versterkt (omdat deze de kans op spijbelen doet dalen).

Het onderhavige onderzoek onderscheidt zich van eerder onderzoek door de omvang van de steekproef en de landelijke steekproeftrekking, die het mogelijk maken om op landelijk niveau inzicht te krijgen in de factoren die spijbelen bevorderen en welke rol een zorgsituatie thuis daarbij speelt. In de steekproef zijn migrantenjongeren ook goed vertegenwoordigd. Een ander sterk punt is dat er gebruik is gemaakt van een analysemethode die het al dan niet spijbelen en het aantal uur spijbelen in één model combineert. Hierdoor is bij de uitkomsten van spijbelintensiteit automatisch rekening gehouden met het al dan niet spijbelen.

Een beperking is dat er geen onderzoek is gedaan onder scholieren op het speciaal voortgezet onderwijs, waar mogelijk vaker sprake is van spijbelgedrag, bijvoorbeeld vanwege leerproblemen, en waar zorgsitu- 
aties wellicht vaker voorkomen [8]. Ook is er weinig bekend over de zorgsituatie zelf. Idealiter zouden we meer willen weten over de aard en ernst van de ziekte, mantelzorgtaken en emotionele problemen die de relatie tussen spijbelintensiteit en zorgsituatie thuis (mede) zouden kunnen verklaren. Nederlands onderzoek heeft namelijk aangetoond dat scholieren met een ziek gezinslid (en dan vooral wanneer dit gezinslid een psychische aandoening heeft) relatief vaak een verminderd welbevinden rapporteren en dat dit samenhangt met zowel de aard als de intensiteit van mantelzorgtaken [14, 19, 30]. Duits onderzoek laat zien dat ongeoorloofd schoolverzuim sterk samenhangt met het welbevinden van scholieren [39]. Onduidelijk is echter of de relatie tussen een zorgsituatie thuis en spijbelgedrag samenhangt met de hoeveelheid of aard van mantelzorgtaken, of dat deze via emotionele of gedragsproblemen loopt [14, 19]. Als dat laatste het geval blijkt te zijn zouden een verminderd welbevinden en het verrichten van veel en mogelijk vooral ziektegerelateerde taken (persoonlijke verzorging en emotionele ondersteuning van de zieke) naast een zorgsituatie thuis en een tekort aan steun, extra aanknopingspunten zijn om spijbelen terug te dringen [14]. Dergelijke aspecten zijn niet in dit onderzoek meegenomen en verdienen meer aandacht in vervolgonderzoek.

Daarnaast lijkt het voor vervolgonderzoek relevant om niet alleen naar de relatie tussen spijbelen en de zorgsituatie thuis te kijken, maar ook de samenhang met ziekteverzuim onder de loep te nemen. Zo werd ziekte in dit onderzoek genoemd als reden voor de afwezigheid van scholieren en vond eerder regionaal onderzoek al dat ziekteverzuim vaak voorkomt onder scholieren met een zorgsituatie thuis [19].

De aanpak van spijbelen zal vermoedelijk de komende tijd een belangrijk aandachtspunt blijven, zeker nu uit recent onderzoek is gebleken dat het aandeel jongeren dat zich hieraan schuldig maakt, toegenomen is van 9 naar $13 \%$ [27]. Het is te verwachten dat het aantal scholieren dat met een ziek gezinslid opgroeit de komende jaren zal toenemen. Steeds meer jongeren wonen in eenoudergezinnen waarin ook geregeld sprake is van armoedeproblematiek, werkloosheid of ziekte van de ouder [40, 41]. Een groot deel van hen geeft ook ondersteuning aan zieke naasten [14]. Dit onderzoek wijst uit dat de aanwezigheid van een zorgsituatie thuis (en daarmee mogelijk een beroep op hulp) bij scholieren ook een toename van het aantal spijbeluren met zich meebrengt. Het verbeteren van de signalering en ondersteuning van scholieren met een zorgsituatie thuis is dan ook van groot belang voor gemeenten, onderwijsinstellingen en beleidsmakers in onderwijs en zorg om het spijbelen op middelbare scholen terug te dringen. Als mentor of zorgcoördinator met ouders en leerlingen het gesprek aangaan over het spijbelgedrag in relatie tot de zorgsituatie thuis kan al een eerste aanzet hiervoor zijn [42].
Open Access This article is licensed under a Creative Commons Attribution 4.0 International License, which permits use, sharing, adaptation, distribution and reproduction in any medium or format, as long as you give appropriate credit to the original author(s) and the source, provide a link to the Creative Commons licence, and indicate if changes were made. The images or other third party material in this article are included in the article's Creative Commons licence, unless indicated otherwise in a credit line to the material. If material is not included in the article's Creative Commons licence and your intended use is not permitted by statutory regulation or exceeds the permitted use, you will need to obtain permission directly from the copyright holder. To view a copy of this licence, visit http://creativecommons.org/licenses/by/4.0/.

\section{Literatuur}

1. Ministerie van Onderwijs, Cultuur en Wetenschap. Cijfers schoolverzuim en vrijstellingen funderend onderwijs. Brief van de minister voor Basis- en Voortgezet Onderwijs en Media aan de voorzitter van de Tweede Kamer der StatenGeneraal van 19 februari 2018. Den Haag: Ministerie van OCW;2018.

2. Gommans R, Roos S de. Schoolbeleving. In: de Looze M, van Dorsselaer S, de Roos S, Verdurmen J, Stevens G, Gommans R, et al., redactie. HBSC 2013. Gezondheid, welzijn en opvoeding van jongeren in Nederland. Ridderkerk: Ridderprintbv;2014. pag. 27-44.

3. Baat $\mathrm{M}$ de. Beschermende en risicofactoren voor schoolverzuim. Utrecht: Nederlands Jeugdinstituut; 2009. http://www.nji.nl/nl/Download-NJi/Risicofactoren_ Schoolverzuim.pdf.

4. Henry K, Knight K, Thornberry T. School disengagement as a predictor of dropout, delinquency, and problem substance use during adolescence and early adulthood. JYouth Adolesc. 2012;2:156-66.

5. Garase ML. Truancy and school dropout. Encycl Juv Delinq Justice. 2017;1:4.

6. GoldsteinJS,LittleSG,Akin-LittleKA.Absenteeism: areview of the literature and school psychology's role. Calif Sch Psychol. 2003;8:127-39.

7. Kearney CA. School absenteeism and school refusal behavior in youth: a contemporary review. Clin Psychol Rev. 2008;28:451-71.

8. Reid K. The causes, views and traits of school absenteeism and truancy: an analytical review. Res Educ. 2005;74:59-82.

9. Henry KL. Who's skipping school: characteristics of truants in 8th and 10th grade. J Sch Health. 2007;77:29-35.

10. Dahl P. Factors associated with truancy: emerging adults' recollections of skipping school. J Adolesc Res. 2016;31:119-38.

11. Chen C, Culhane D, Metraux S, Park J, Venable J. The heterogeneity of truancy among urban middle school students: a latent class growth analysis. J Child Fam Stud. 2016;25:1066-75.

12. Jeugdzorg Nederland. Methodische handreiking schoolverzuim jeugdreclassering. Utrecht: Jeugdzorg Nederland; 2011.

13. Kim H, Page T. Emotional bonds with parents, emotion regulation, and schoolrelated behavior problems among elementary school truants. JChild Fam Stud. 2012;22:869-78.

14. Roos S de, Boer A de, Bot S. Well-being and need for support of adolescents with a chronically ill family member. J Child Fam Stud. 2017;26:405-15.

15. Sieh D, Visser-Meily A, Meijer A. Jonge mantelzorger heeft behoefte aan aandacht. Jeugd En Co. 2011;5:18-26. 
16. Boer A de, Oudijk D, Tielen L. Kinderen en jongeren met een langdurig ziek gezinslid. Nederland. Tijdschr Gezondheidswet. 2012;90:167-70.

17. Ministerie van Volksgezondheid, Welzijn en Sport. Kinderen van een langdurig zieke ouder. Brief van de minister van VWS aan de voorzitter van de Tweede Kamer der StatenGeneraal van 18 juni 2018. Den Haag: Ministerie van VWS; 2018.

18. De Kinderombudsman. Hoor je mij wel? Kinderen van ouders met een ziekte, verslaving of beperking. Den Haag: De Kinderombudsman; 2018.

19. Einde-Bus AEM van den, Goldschmeding JEJ van den, Tielen LM, Waart FG de, Looij-Jansen PM. Jongeren die opgroeien met een langdurig ziek, gehandicapt of verslaafd familielid: reden tot zorg. Tijdschr Gezondheidswet. 2010;88:79-88.

20. Dearden C, Becker S. Young carers and education. London: Carers UK; 2002.

21. Siskowski C. Young caregivers: effect of family health situations on school performance. JSch Nurs. 2006;22:163-9.

22. Bakker I, Bakker K, Dijke A van. $0+0=02$ : naar een samenhangend beleid en aanbod van opvoedingsondersteuning en ontwikkelingsstimulering voor kinderen en ouders in risicosituaties. Utrecht: NIZW; 1998.

23. Vaughn M, Maynard B, Salas-Wright CP, Perron B, Abdon A. Prevalence and correlates of truancy in the US: results from a national sample. J Adolesc. 2013;36:767-76.

24. Hughes JN, Cao Q. Trajectories of teacher-student warmth and conflict at the transition to middle school: effects on academic engagement and achievement. J Sch Psychol. 2018;67:148-62.

25. Košir K, Tement S. Teacher-student relationship and academic achievement: a cross-lagged longitudinal study on three different age groups. Eur J Psychol Educ. 2014;29:409-28.

26. Wilson W, Malcolm H, Edwards S, Davidson J. 'Bunking off': the impact of truancy on pupils and teachers. Br Educ Res J. 2008;34:1-17.

27. Stevens G, Dorsselaer S de, Boer M, Roos S de, Duinhof E, Visser D, et al. HBSC 2017. Gezondheid, welzijn en de sociale context van jongeren in Nederland. Ridderkerk: Ridderprint bv; 2018.

28. Armistead L, Klein K, Forehand R. Parental physical illness and child functioning. Clin Psychol Rev. 1995;15:409-22.
29. Drost LM, Schippers GM. Online support for children of parents suffering from mental illness: a case study. Clin Child Psychol Psychiatry. 2015;20:53-67.

30. Roos S de, Bot S, Boer A de. Psychisch welbevinden van jongeren met een langdurig ziekgezinslid. Tijdschr Orthop. 2013;52:212-23.

31. Bodén L. Presentabsences. Exploring the posthumanistentanglements of school absenteeism. Linköping: Linköping University; 2016.

32. LoozeMde, DorsselaerS, Roos Sde, Verdurmen J, Stevens G, Gommans R, et al. Gezondheid, welzijn en opvoeding van jongeren in Nederland. HBSC 2013. Ridderkerk: Ridderprintbv; 2014

33. Inchley J, Currie D, Young T, Samdal O, Torsheim T, Augston L, Barnekow V. Growing up unequal: gender and socioeconomic differences in young people's health and wellbeing. Health Behaviour in School-aged Children (HBSC) study: international report from the 2013/2014 survey. København: WHO Regional Office for Europe; 2016.

34. Zimet G, Dahlem N, Zimet S, Farley G. The multidimensional scale of perceived social support. J Pers Ass. 1988;52:30-41.

35. Greene W. Accounting for excess zeros and sample selection in Poisson and negative binomial regression models. Working Paper EC-94-10. New York: New York University; 1994.

36. Kaiser S, Schulze G. Between inclusion and participation: young carers who are absent from school. J Cogn Educ Psychol. 2015;14:314-28.

37. Engels R, Bogt $\mathrm{T}$ ter. Influences of risk behaviors on the quality of peer relations in adolescence. J Youth Adolesc. 2001;30(6):675-95.

38. RoebuckM,French M, Dennis M.Adolescentmarijuana use and school attendance. Econ Educ Rev. 2004;23:133-41.

39. Lenzen CFG, Jentzsch A, Kaess M, Parzer P, Carli V, Wasserman D, et al. Schulabsentismus in Deutschland - die Prävalenz von entschuldigten und unentschuldigten Fehlzeiten und ihre Korrelation mit emotionalen und Verhaltensauffälligkeiten. Prax Kinderpsychol Kinderpsychiatr. 2013;62:570-82.

40. CBS. Kwaliteit van leven. Den Haag: CBS; 2017.

41. CBS. Bijna 1 op de 10 baby's wordt geboren in oudergezin. Den Haag: CBS; 2018.

42. Roos S de, Boer A de, Janssens H. Zorgcoördinatoren over de signalering van jonge mantelzorgers. Bij De Les. 2017;13:9-11. 